\title{
Feeling of Safety among Residents in Metropolitan Lagos, Nigeria
}

\author{
Pius Enechojo Adejoh \\ Senior Lecturer, Department of Sociology \\ Faculty of Social Sciences, University of Lagos. Akoka
}

\begin{abstract}
This study examines the social factors that underpin the feeling of safety among residents in metropolitan Lagos. The paper is anchored on the instrumental and expressive theories of fear of crime and feeling of safety. It utilized quantitative data that were generated from 1,107 community members aged 18 who were drawn from four Local Government Areas of Lagos state. The study found a strong positive association between sex, employment, ethnicity, income; perceived neighbourhood crime level, experience of victimization, neighbourhood disorderliness and feeling of safety.It was recommended that relevant agencies of government-the police especially, must strive harder to improve citizens' feeling of safety, because of its profound implications for the flourishing of democracy, economic development, social capital, associational life and the quality of life.
\end{abstract}

Key words: Fear of crime; Feeling of Safety; Neighbourhood disorder; Lagos; Nigeria.

\section{INTRODUCTION}

Social life in Nigeria has remained largely characterized by fear and insecurity (Odinkalu, 2005). This derives largely from the rising wave of crime and criminal victimization across the country. From the conventional crimes of petty stealing, breaking into homes, snatching of purses by thugs, and in extreme cases, armed robbery on the high ways, crime has grown in form, complexity, sophistication and deadliness. Some of the new additions in this regard include such crimes as kidnapping, abduction, hostage taking, assassinations, ritual killing, terrorism and suicide bombing. Nigerians are also buffeted by an array of other criminals including fraudsters, scammers, cultists and armed street gangs. Added to these are the frequent and sporadic outbursts of religious, ethnic and communal violence, all of which combine to paint a picture of a country that is under siege and where the fear of crime and victimization has become the common denominator of existence. The nightmare is further compounded by the fact that these crimes do not make any distinctions in terms of place, age, sex, status and even circumstances. Unsure therefore of whom the next victim would be, where, when and how, most citizens now live in fear and trepidation.

This paper set out to examine some of the variables that influence feeling of safety among residents of Lagos. The study became necessary against the backdrop of the implications of crime, crime victimization and poor feeling of public safety for the flourishing of democracy, economic development, social capital, associational life and the quality of life of citizens. The paper is divided into seven related parts, with this introductory part as the first. Part two of the paper discusses the problemmatique of the study while section three deals with definitional issues. The fourth section addresses the theoretical premise of the paper while section five outlines the methodology adopted in the work. The sixth section discusses the findings of the study while the seventh and final section concludes the work and makes policy recommendations. 


\section{THE PROBLEM}

Crime and insecurity have remained endemic in Nigeria. In its 2015 Crime and Safety Report, OSAC, a unit of the United States Bureau of Diplomatic Security described the crime situation in the country as 'critical'. The report revealed that U.S visitors and residents in Nigeria experienced armed muggings, assaults, burglaries, carjacking, rapes, kidnappings, and extortion. Other common crimes and safety concerns raised in the report include armed robbery, cyber criminality, and lawlessness on our roads, piracy, militancy, impunity and harassment by security officials, civil unrest, political, economic, religious and ethnic violence, and local, regional, and international terrorism. About the Nigeria Police, the report said:

"Law enforcement authorities usually respond slowly or not at all and provide little/no investigative support to victims....Local police... generally do not deter or disrupt burglaries and other crimes and seldom apprehend or detain suspects after the fact".

(https://www.osac.gov/pages/ContentReportDetails.aspx?cid=17598).

On August 3, 2016, the U.S Department of State- Bureau for Consular Affairs -issued another travel warning, where it declared 20 of Nigeria's 36 states and Abuja as unsafe for American citizens to travel to. (https://travel.state.gov/content/passports/en/alertswarnings/nigeriatravel-warning.html). Again, the same reason of insecurity was invoked.

In what appears to be a corroboration of the bizarre picture painted above by the U.S Department of State, a 2013 crime victimization survey by CLEEN Foundation reported that 7 out of every 10 Nigerians or $72 \%$ had the fear of becoming victims of crime. Indeed, $25 \%$ of a total 11,518 respondents who took part in the survey had been victims of crime during the past year. The figure of respondents who had been victims of crime in Lagos state in the past year was 18 percent. In an earlier National Crime \& Safety Survey conducted in 2012, the same organization had found that about 67 percent of Lagos residents said they had fear of becoming a victim of crime while 23 percent agreed to have experienced crime in the last one year, with the general perception being that crime rate increased from 12 percent to 21 percent in Lagos State during the year under review

Scholars have often worried about the social and economic outcomes of the individual responses to the fear of crime and feelings of insecurity (Garofalo, 1981). According to Conklin (1975) crime produces fear, and responses to fear often engender such negative social outcomes as heightened interpersonal distrust, withdrawal of support from the systems of formal authority devised to control crime, and decreased levels of social interaction. He adds that the latter, leads to a weakening of informal social controls in the area affected and in turn, leads to an even greater amount of crime. Other features thought to characterize this cycle are the closing of businesses in an area and the moving away of the area's more affluent residents, both of which tend to decrease the area's tax base and depress the situation even further.

In relation to Nigeria, concerns about safety and security have led not only to loss of business confidence but indeed, to loss of the much needed foreign direct investment into the country. Indeed, as the security situation in the country becomes more worrisome, the respect of Nigeria in the eyes of the international community continues to diminish (http://www.myfinancialintelligence.com/professional-services/cost-and-effect-insecuritynigeria). This dims the hope of providing jobs for the country's army of unemployed youth and vitiates the country's efforts at fast tracking her socio economic development.

Perceptions of high insecurity are also known to have a negative effect on support and satisfaction with democracy because individuals often have high expectations about the 
outcomes of a democratic system and are thus likely to be disappointed if these expectations are not forthcoming (Chinchilla, 2002). It is not uncommon these days to hear Nigerians reminisce about the military era and openly canvass for stronger leaders that can take authoritarian measures against crime. Extant literature also reveal how crime victimization provoked increased support for military coups in El Salvador in the past and as well decreased support for the political and judicial system in Latin American countries (Cruz 2006, Malone 2010).

It is against the foregoing background that this study examines the social factors that influence the feeling of safety among residents of metropolitan Lagos. The expectation is that the study will provide illumination on the influence of specific socio-demographic variables such as age, sex, employment, ethnicity etc; perceived neighbourhood crime level, prior experience of victimization, perception of likelihood of victimization (risk), neighbourhood civility, neighbourhood police presence and level of confidence in the formal police perceptions of safety in the state. This will also help in providing a road map for bridging existing gaps, with a view to safeguarding our democracy and enhancing the development of Lagos state.

\section{DEFINITION OF CONCEPTS}

Crime: This concept is used in this paper to refer to any form of behaviour and or action that violates the provisions of the criminal code of the country. A crime victim on the other hand, is any person who suffers harm whether physical or psychological as a result of crime.

The fear of crime: This relates to the feeling of anxiety or dread of becoming a victim of crime. It relates more to the feelings, thoughts and behaviours about being at the risk of crime victimisation as against the actual probability of being a victim of crime. Literature indicate that fear of crime has adverse implications for public health and psychological well-being; it can also alter routine activities and habits; contribute to some places turning into 'no-go' areas via a withdrawal from community; and drain community cohesion, trust and neighborhood stability (Jackson and Stafford, 2009)

Safety: This term refers to the condition of freedom or protection of the human person from victimisation and avoidable injuries and death. It is sometimes used interchangeably with security which in the context of criminal victimization, refers to the guarantee of citizens' lives and properties from theft, acts of violence and unwarranted destruction. In this study, perception of safety is also used interchangeably with fear of crime. Baba and Mark (1989) had earlier argued that fear of crime is synonymous with the perception of safety.

Neighbourhood disorder or incivility: This is used to refer to any aspect of the social and physical environment that indicates to the observer (a) a lack of control and concern and (b) the values and intentions of others that share the space (Jackson and Sunshine, 2007). Ferraro (1995:15) uses the term incivilities to describe low level breaches of community standards that signal an erosion of conventionally accepted norms and values. In this study, incivility was measured by a composite analysis of a range of variables including drug use, sexual harassment, street gang violence, and car vandalism. Studies indicate that incivilities provided ecological information that shaped citizens' perceptions of the chances of victimization and of feeling of safety (Jackson and Sunshine, 2007).

\section{THEORETICAL FRAMEWORK}

This study is anchored on the instrumental and expressive theories of fear of crime or of feeling of safety from crime. The experience/instrumental theory suggests that feeling of safety and fear of crime are the result of personal or vicarious experiences of crime and criminal 
victimization (Tyler and Boeckmann 1997). It adds that worries or anxieties about personal safety and of crime victimisation are additionally, heightened by sensational media coverage that brings an awareness of crime into people's everyday lives. In other words, fear of crime or of safety from crime are driven largely by direct experience of victimization, severity of the level of criminal activity or by what people hear about criminal activity- either from conversations with others or from the mass media (Bennett, 1990).Skogan (1986:203) used the term 'primary and secondary knowledge of neighbourhood crime rates' to describe these situations that are also referred to as direct and indirect victimization in literature. Hale (1996) found that hearing of friends' or neighbours'victimisation increases anxiety and that indirect experiences of crime may play a stronger role in anxieties about victimisation than even direct experience. Jackson, Bradford, Hohl and Farrall (2009) observed that direct and indirect victimization and sensational media reports of crime impinge directly on public confidence in the ability of the police to guarantee safety and this in turn, compounds anxieties about victimization or safety from crime. Lagos state has continued to work hard to improve the security since the return to civil rule in 1999 but media reports about crime have remained disturbing. From the stand point of this theory, these direct and reported accounts of crime and criminal victimizations have profound implications for the fear of crime or feeling of safety among residents.

However, much as there are empirical evidences that support the argument of instrumental theory that fear of crime or perceptions of safety from crime is partly the product of actual victimization experience, perceived risk of victimization or even perception about the severity of crime, some scholars have argued that the theoretical model is limited by its inability to explain why fear of crime or perception of safety from crime remains high among people who are less likely to fall victim (Hale, 1996). It is this obvious handicap of the instrumental thesis that informed the adoption of a second -expressive - theoretical model which explains fear of crime or perception of safety from crime as being the product of people's lay assessments of neighbourhood conditions including such things as levels of disorder, lack of civility, trust and social control, all of which reflect concerns about the breakdown and fragmentation of society (Jackson, 2004: 946). Signs of neighbourhood breakdown and the deterioration of social controls approximate what Ferraro (1995:15) calls incivilities and are typified by the presence of low-level breaches of community standards that signal an erosion of conventionally accepted norms and values. In this study, these breaches were measured by the composite analysis of four variables- drug use, sexual harassment, street gang violence and car vandalism in study communities. Jackson and Sunshine (2007) contend that the presence of disorder and incivilities in a neighbourhood represents an affront on shared values and norms and that this does not only adversely affect public confidence in the police, but also raises the level of fear of victimisation. This is because people look to the police to defend community values and moral structures, especially when they believe these structures to be under threat, and when they fail to do this, as the presence of incivilities suggest, the people lose confidence in the police to reduce crime and provide safety. This may as well explain the low level of public confidence and satisfaction with the police in this study.

\section{METHODOLOGY}

The study adopted the survey research design to generate quantitative data from Ikeja, Mushin, Ikorodu and Eti-Osa Local Government Areas of Lagos State. Respondents were community members aged 18years and above and were sampled proportionally through multistage sampling technique involving the random selection of LGAs, enumeration areas (EAs), households and finally, respondents. A total of 1,107 respondents took part in the study. Data for the study were analyzed using frequencies, simple percentages and chi-square statistics with the alpha set at 0.05 level of significance. 


\section{FINDINGS}

\section{Demographic and socio economic characteristics of respondents}

As seen in table 1 below, there were near equal proportions of male and female respondents in the study. Also, the respondents' mean age was 39 years and were mostly Yoruba, even though there was a fair representation of Nigeria's other major as well as a few other minority ethnic groups. Nearly 70percent of the respondents were married at the time of the study while majority (96.7percent) had a minimum of primary school education. Similarly, about 83 percent of the respondents were employed with the average monthly income of respondents standing at N44, 610.97.

Table I: Percentage distribution of respondents by background characteristics

\begin{tabular}{|c|c|c|c|}
\hline \multicolumn{2}{|c|}{ Demographic/Socio-economic Characteristics } & Frequency $\mathrm{N}=1017$ & Percent (\%) \\
\hline Sex Distribution & $\begin{array}{r}\text { Male } \\
\text { Female }\end{array}$ & $\begin{array}{l}559 \\
458\end{array}$ & $\begin{array}{l}55.0 \\
45.0\end{array}$ \\
\hline Age Distribution & $\begin{array}{l}\text { Less than } 20 \text { Years } \\
20-29 \text { Years } \\
30-39 \text { Years } \\
40-49 \text { Years } \\
50-59 \text { Years } \\
60 \text { Years }+ \\
\text { Mean age }=39 \text { years }\end{array}$ & $\begin{array}{c}14 \\
242 \\
307 \\
265 \\
111 \\
69\end{array}$ & $\begin{array}{c}1.4 \\
24.0 \\
30.5 \\
26.3 \\
11.0 \\
6.8\end{array}$ \\
\hline Marital Status & $\begin{array}{l}\text { Single } \\
\text { Married } \\
\text { Divorced } \\
\text { Separated } \\
\text { Widowed }\end{array}$ & $\begin{array}{c}261 \\
710 \\
14 \\
15 \\
17\end{array}$ & $\begin{array}{c}25.7 \\
69.8 \\
1.4 \\
1.5 \\
1.7\end{array}$ \\
\hline Ethnic Background & $\begin{array}{l}\text { Yoruba } \\
\text { Igbo } \\
\text { Hausa } \\
\text { Others }\end{array}$ & $\begin{array}{c}692 \\
226 \\
21 \\
78\end{array}$ & $\begin{array}{c}68.0 \\
22.2 \\
2.1 \\
7.7\end{array}$ \\
\hline Religion & $\begin{array}{l}\text { Christianity } \\
\text { Islam } \\
\text { African Traditional Religion } \\
\text { Others }\end{array}$ & $\begin{array}{c}655 \\
325 \\
32 \\
5\end{array}$ & $\begin{array}{c}64.4 \\
32.0 \\
3.2 \\
0.5\end{array}$ \\
\hline Education & $\begin{array}{l}\text { No formal education } \\
\text { Primary education } \\
\text { Secondary education } \\
\text { Tertiary education }\end{array}$ & $\begin{array}{c}34 \\
103 \\
516 \\
364\end{array}$ & $\begin{array}{c}3.3 \\
10.1 \\
50.7 \\
35.8\end{array}$ \\
\hline Employment & $\begin{array}{l}\text { Employed } \\
\text { Unemployed } \\
\text { Student/Apprenticeship } \\
\text { Others }\end{array}$ & $\begin{array}{c}846 \\
66 \\
82 \\
23\end{array}$ & $\begin{array}{c}83.2 \\
6.5 \\
8.1 \\
2.3\end{array}$ \\
\hline Monthly Income & $\begin{array}{l}\text { Less than N20,0000 } \\
\text { N20,000-N39,999 } \\
\text { N40,000 - N59,999 } \\
\text { N60,000 -N79,999 } \\
\text { N80,000 - N99,999 } \\
\text { N100,000+ } \\
\text { No Response } \\
\text { Mean Income=N44, 610.97. }\end{array}$ & $\begin{array}{c}106 \\
263 \\
176 \\
80 \\
40 \\
122 \\
230\end{array}$ & $\begin{array}{c}10.4 \\
25.9 \\
17.3 \\
7.9 \\
3.9 \\
12.0 \\
22.6\end{array}$ \\
\hline
\end{tabular}

\section{Test of Relationships}

Seven hypotheses were tested for this study. The first hypothesis tested the influence of residents' perception about the level of crime in Lagos state on their feeling of safety from 
crime (see table 2). Of the 219 respondents and 240 respondents respectively, who considered the level of crime in the state to be either extremely high or somewhat high, about 28percent and another 34percent in that order, reported that they feel unsafe or are afraid of crime victimization in their neighbourhoods. Similarly, nearly 23percent and 24percent respectively of those who adjudged crime level to be either extremely high or somewhat high, in the state reported that they feel just safe in their neighbourhoods, while only 11percent and 14percent respectively of those who considered crime level in the state to be either extremely high or somewhat high reportedly feel very safe in their neighbourhoods. Interestingly, as high as 33.5percent of respondents who considered the level of crime in the state to be average reported that they feel unsafe in their neighbourhoods. A chi test analysis of data indicated a calculated value (x2) of 99.417, a degree of freedom of 8 and a p-value of 0.000 . This is interpreted to mean that a very strong relationship does exist between perceived level of crime in Lagos state and feeling of safety among residents of the state people.

Table II: Relationship between Perceived level of crime in Lagos state and feeling of safety Cross tabulation

\begin{tabular}{|c|c|c|c|c|c|c|c|c|c|c|}
\hline & \multicolumn{5}{|c|}{ Perceived Level of Crime in Lagos state } & \multirow[b]{2}{*}{ Total } & \multirow[b]{2}{*}{$D f$} & \multirow[b]{2}{*}{$\chi^{2}$} & \multirow[b]{2}{*}{ P.Value } \\
\hline & & $\begin{array}{c}\text { Extremely } \\
\text { High }\end{array}$ & $\begin{array}{c}\text { Somewhat } \\
\text { High }\end{array}$ & Average & $\begin{array}{l}\text { Somewhat } \\
\text { Low }\end{array}$ & $\begin{array}{l}\text { Extremely } \\
\text { Low }\end{array}$ & & & & \\
\hline \multirow{4}{*}{$\begin{array}{l}\text { Respondents' } \\
\text { feeling of safety } \\
\text { walking alone at } \\
\text { night in their } \\
\text { neighbourhoods }\end{array}$} & $\begin{array}{l}\text { Very } \\
\text { Safe }\end{array}$ & $18(11.0)$ & $22(13.5)$ & $22(13.5)$ & $57(35.0)$ & $2(1.2)$ & $163(100.0)$ & \multirow{4}{*}{8} & \multirow{4}{*}{99.417} & \multirow{4}{*}{.000} \\
\hline & $\begin{array}{l}\text { Just } \\
\text { Safe }\end{array}$ & $153(22.6)$ & $\begin{array}{c}159 \\
(23.5)\end{array}$ & $286(42.3)$ & $74(10.9)$ & $4(.6)$ & $676(100.0)$ & & & \\
\hline & Unsafe & $48(27.7)$ & $59(34.1)$ & $58(33.5)$ & $8(4.6)$ & $0(.0)$ & $173(100.0)$ & & & \\
\hline & Total & $219(21.6)$ & $240(23.7)$ & $408(40.3)$ & $139(13.7)$ & $6(.6)$ & $1012(100.0)$ & & & \\
\hline
\end{tabular}

The second hypothesis examined the influence of residents' perception about the frequency of crime in their immediate neighbourhoods on their feeling of safety from crime (see table 3). A total of 127 of 1007 respondents reported that crime takes place quite often in their neighbourhoods. Of this, 38.2percent reported that they feel unsafe walking alone at night in their neighbourhoods, about eight percent feel just safe while six percent feel very safe. Of the 316 who reported that crime occurred often in their neighbourhoods, 43.4 percent feel unsafe walking alone at night, 33.3percent feel just safe while 12.2percent feel very safe. Over a half (564) of the 1007 respondents reported that crime did not occur often in their neighbourhoods. Even then, $19.4 \%$ of them feel unsafe while another 58.8percent feel just safe walking alone at night in their neighbourhoods. A chi test analysis of data indicate that a very strong relationship does exist between perceived frequency of crime in respondents' immediate neighbourhoods and feeling of safety among residents of Lagos state. This is indicated by a calculated value (x2) of 195.492, a degree of freedom of 4 and a p-value of 0.000 as is seen in the table above. This presupposes that people are very much likely to feel unsafe if they perceive or consider that crime is a regular occurrence in their neighbourhoods.

Table III: Relationship between perceived frequency of crime in residents' neighbourhoods and feeling of safety

\begin{tabular}{|c|c|c|c|c|c|c|c|c|}
\hline & & \multicolumn{3}{|c|}{$\begin{array}{l}\text { The frequency of the occurrence of } \\
\text { criminal activities in your } \\
\text { neighbourhood }\end{array}$} & \multirow[b]{2}{*}{ Total } & \multirow[b]{2}{*}{$D f$} & \multirow[b]{2}{*}{$x 2$} & \multirow[b]{2}{*}{ P.Value } \\
\hline & & Very Often & Often & Not Often & & & & \\
\hline \multirow{4}{*}{$\begin{array}{l}\text { Respondents' feeling of } \\
\text { safety walking alone at } \\
\text { night in their } \\
\text { neighbourhoods }\end{array}$} & Very Safe & $9(5.5)$ & $20(12.2)$ & $135(82.3)$ & $164(100.0)$ & \multirow{4}{*}{4} & \multirow{4}{*}{195.492} & \multirow{4}{*}{.000} \\
\hline & Just Safe & $53(7.9)$ & $224(33.3)$ & $396(58.8)$ & $673(100.0)$ & & & \\
\hline & Unsafe & $65(38.2)$ & $72(42.4)$ & $33(19.4)$ & $170(100.0)$ & & & \\
\hline & Total & $127(12.6)$ & $316(31.4)$ & $564(56.0)$ & $1007(100.0)$ & & & \\
\hline
\end{tabular}

The third hypothesis looked at how residents' experience of criminal victimization affected their feeling of safety (see table 4). A total of 291 of 1015 respondents reported that either they 
or a member of their family had been a victim of crime in their neighbourhoods before. Of this, 51.7percent reported that they feel unsafe in their neighbourhoods, 26.8percent feel just safe while 11.7 percent feel very safe. Of the 724 respondents who reported that neither they nor their family members had been a victim of crime in their neighbourhoods before, 48.3percent feel unsafe, 73.2percent feel just safe while 88.3percent feel very safe. A chi test analysis of data indicated a calculated value (x2) of 69.399, a degree of freedom of 4 and a p-value of 0.000 (see table 4). This is interpreted to mean that people who or whose family members had been victims of crime before are very much likely to feel unsafe in a particular environment. With respect to this study, residents of Lagos who or whose family member(s) had been a victim of crime feel unsafe or are afraid of crime victimization in their neighbourhoods. This finding agrees with the works of Silverman and Della-Guistina, (2001) and Alemika et al. (2006) who reported that perceptions about community safety and security are affected by personal experience or reports by relatives and acquaintances. Grabosky (1995) adds further that prior victimisation, both directly or indirectly through the experience of family and friends, can have 'long lasting impacts on the victims and those close to them', heightens awareness of the risk of crime and is strongly associated with fear of crime or feeling of safety.

Table IV: Relationship between experience of criminal victimization and feeling of safety among residents in Lagos state.

\begin{tabular}{|c|c|c|c|c|c|c|c|}
\hline & \multicolumn{2}{|c|}{$\begin{array}{l}\text { Have you or any member of } \\
\text { your family been a victim of } \\
\text { crime in your neighbourhood }\end{array}$} & \multirow[b]{2}{*}{ Total } & \multirow[b]{2}{*}{$D f$} & \multirow[b]{2}{*}{$x 2$} & \multirow[b]{2}{*}{ P.Value } \\
\hline & & Yes & No & & & & \\
\hline \multirow{4}{*}{$\begin{array}{l}\text { Respondents' feeling of } \\
\text { safety walking alone at } \\
\text { night in their } \\
\text { neighbourhoods }\end{array}$} & Very Safe & $19(11.7)$ & $144(88.3)$ & $163(100.0)$ & \multirow{4}{*}{4} & \multirow{4}{*}{69.399} & \multirow{4}{*}{.000} \\
\hline & Just Safe & $182(26.8)$ & $496(73.2)$ & $678(100.0)$ & & & \\
\hline & Unsafe & $90(51.7)$ & $84(48.3)$ & $174(100.0)$ & & & \\
\hline & Total & $291(28.7)$ & $724(71.3)$ & $1,015(100.0)$ & & & \\
\hline
\end{tabular}

The fourth hypothesis examined the relationship between reported presence of police patrol teams in respondents' neighbourhoods and their feeling of safety (see table 5). The table indicates that of the 1016 respondents in this study, only 415 or 40.8 percent see police patrol teams in their neighbourhoods every day. About $13 \%$ see Police patrol teams at least once weekly, 36percent see Patrol teams infrequently while nine percent have never seen Police patrol teams in their streets. Incidentally, fear of criminal victimization or feeling of unsafety appears to be higher among residents who see Police patrol teams daily (46.6 percent) and those who see Police patrol teams infrequently (29.3percent) in their streets. As shown in the table, the chi-square value for the test of significance of the degree of association between physical presence of the Police in a neighbourhood and feeling of safety was calculated to be 59.897, which is quite significant with 8 degrees of freedom. This implies that the regular presence of police patrol teams has a way of reassuring residents of their safety from crime.

The above result is corroborated by the work of Doyle, Frogner, Andershed and Andershed (2016) who found that while it is true that all types of uniformed presence increased feelings of safety in situations perceived as relatively unsafe, it did not increase feelings of safety in a situation perceived as relatively safe, thus making patrol unnecessary is such settings.Veer, Lange, Haar and Karreemans J.C (2012) also who reported that in environments that are generally considered to be safe, feeling of safety are not increased by police presence and that indeed men feel less safe when police are present compared with when they are absent. 
Table V: Relationship between Presence of Police patrol teams in neighbourhoods and feeling of safety among residents in Lagos state.

\begin{tabular}{|c|c|c|c|c|c|c|c|c|c|c|}
\hline & \multicolumn{5}{|c|}{$\begin{array}{l}\text { Frequency of seeing police patrolling your street Cross } \\
\text { tabulation }\end{array}$} & \multirow[b]{2}{*}{ Total } & \multirow[b]{2}{*}{$D f$} & \multirow[b]{2}{*}{$\chi 2$} & \multirow[b]{2}{*}{ P.Value } \\
\hline & & Daily & Weekly & Monthly & Infrequently & Never & & & & \\
\hline \multirow{4}{*}{$\begin{array}{l}\text { Respondents' } \\
\text { feeling of safety } \\
\text { walking alone at } \\
\text { night in their } \\
\text { neighbourhoods }\end{array}$} & $\begin{array}{l}\text { Very } \\
\text { Safe }\end{array}$ & 96 (58.5) & 31 (18.9) & $0(.0)$ & 27 (16.5) & $10(6.1)$ & $164(100.0)$ & \multirow{4}{*}{8} & \multirow{4}{*}{59.897} & \multirow{4}{*}{.000} \\
\hline & $\begin{array}{l}\text { Just } \\
\text { Safe }\end{array}$ & $238(35.1)$ & 78 (11.5) & $6(.9)$ & $290(42.8)$ & $66(9.7)$ & $678(100.0)$ & & & \\
\hline & Unsafe & $81(46.6)$ & 24 (13.8) & $4(2.3)$ & $51(29.3)$ & $14(8.0)$ & $174(100.0)$ & & & \\
\hline & Total & $415(40.8)$ & 133 (13.1) & $10(1.0)$ & $368(36.2)$ & $90(8.9)$ & $1012(100.0)$ & & & \\
\hline
\end{tabular}

The fifth hypothesis tested the effect of respondents' level of confidence in the Police on their feeling of safety (see table 6). Only 55 or $5.5 \%$ of a total 992 respondents who offered a response had great confidence in the Police while majority (801 or 80.7 percent) had little confidence in the Police. Over $80 \%$ of respondents who had little confidence in the Police reported feeling unsafe in their neighbourhoods while another 83.8percent of these reported feeling just safe in their neighbourhoods. The chi-square value (x2) for the test of significance of the degree of association between level of confidence in the Police and feeling of safety was calculated at 70.372 with a degree of freedom of 6 and a p-value of 0.000 , which is significant. This presupposes that residents' feeling of safety is largely influenced by their level of confidence in the Police. With respect to this study, many residents of Lagos have little confidence in the Police to protect them and thus feel unsafe in their neighbourhoods.

Table VI: Relationship between level of confidence in the Police and feeling of safety among residents in Lagos state.

\begin{tabular}{|c|c|c|c|c|c|c|c|c|c|}
\hline & \multicolumn{4}{|c|}{ Level of confidence in the Police } & \multirow[b]{2}{*}{ Total } & \multirow[b]{2}{*}{$D f$} & \multirow[b]{2}{*}{$\chi^{2}$} & \multirow[b]{2}{*}{ P.Value } \\
\hline & & $\begin{array}{c}\text { Great } \\
\text { confidence } \\
\text { in the police }\end{array}$ & $\begin{array}{c}\text { Little } \\
\text { confidence } \\
\text { in the police }\end{array}$ & $\begin{array}{l}\text { Mixed feelings } \\
\text { about the } \\
\text { police }\end{array}$ & $\begin{array}{l}\text { Don't } \\
\text { know }\end{array}$ & & & & \\
\hline \multirow{3}{*}{$\begin{array}{l}\text { How safe do you } \\
\text { feel walking alone } \\
\text { at night in } \\
\text { your } \\
\text { neighbourhood? }\end{array}$} & $\begin{array}{l}\text { Very } \\
\text { safe }\end{array}$ & $30(19.0)$ & $108(68.4)$ & $16(10.1)$ & $4(2.5)$ & 158(100.0) & \multirow{4}{*}{6} & \multirow{4}{*}{70.372} & \multirow{4}{*}{.000} \\
\hline & Just safe & $21(3.2)$ & $555(83.8)$ & $76(11.5)$ & $10(1.5)$ & 662(100.0) & & & \\
\hline & Unsafe & $4(2.3)$ & $138(80.2)$ & $23(13.4)$ & $7(4.1)$ & 172(100.0) & & & \\
\hline Total & Total & $55(5.5)$ & $801(80.7)$ & $115(11.6)$ & $21(2.1)$ & 992(100.0) & & & \\
\hline
\end{tabular}

Hypothesis 6 looked at the effect of respondents' satisfaction with the performance of the Police on their feeling of safety (see table 7). Only 155 or 16.4 percent of a total 944 respondents who offered a response expressed satisfaction with the performance of the Nigeria Police while majority (789 or 83.6percent) were dissatisfied with Police performance. Over $90 \%$ of respondents who expressed dissatisfaction with the performance of the Police reported that they feel unsafe in their neighbourhoods. The chi-square value (x2) for the test of significance of the degree of association between feeling of satisfaction and the feeling of safety was calculated at 46.951 with a degree of freedom of 2 and a p-value of 0.000 , which is significant. This presupposes that residents' feeling of safety also derives from their assessment of the effectiveness of the Police in the discharge of their duties. Clearly, this study indicates that most residents are not satisfied with the performance of the Nigerian Police and this adversely affects their feeling of safety in their neighbourhoods. 
Table vii: Relationship between satisfaction with the performance of the Police and feeling of safety

\begin{tabular}{|c|c|c|c|c|c|c|c|}
\hline & \multicolumn{2}{|c|}{$\begin{array}{l}\text { Are you satisfied with the } \\
\text { performance of the Police in } \\
\text { providing security in your area? }\end{array}$} & \multirow[t]{2}{*}{ Total } & \multirow[t]{2}{*}{$D f$} & \multirow[t]{2}{*}{$\chi^{2}$} & \multirow[t]{2}{*}{ P.Value } \\
\hline & & Yes & No & & & & \\
\hline \multirow{3}{*}{$\begin{array}{l}\text { How safe do you feel } \\
\text { walking alone at } \\
\text { night in your } \\
\text { neighbourhood? }\end{array}$} & Very safe & $54(34.4)$ & $103(65.6)$ & $157(100.0)$ & \multirow{4}{*}{2} & \multirow{4}{*}{46.951} & \multirow{4}{*}{. 000} \\
\hline & Just safe & 87 (13.9) & $538(86.1)$ & $625(100.0)$ & & & \\
\hline & Unsafe & $14(8.6)$ & $148(91.4)$ & $162(100.0)$ & & & \\
\hline Total & Total & $155(16.4)$ & $789(83.6)$ & $944(100.0)$ & & & \\
\hline
\end{tabular}

Hypothesis seven examined the influence of residents' perception of the level of disorderliness of their neighbourhoods and on feeling of safety (see table 8). Most (953 or 94percent) of a total of 1014 residents adjudged their neighbourhoods to be fairly disorderly in terms of the presence of such conducts as drug abuse, car vandalism, street gang assault and violence, and sexual harassment. Of this, only $14.7 \%$ reported that they felt very safe to walk alone in their neighbourhoods at night while 68.9percent felt just safe to walk alone in their neighbourhoods at night. Another 14.6percent and about two percent of those who adjudged their neighbourhoods to be fairly disorderly felt it was unsafe and very unsafe respectively, to walk alone at night in their neighbourhoods. The chi-square value (x2) for the test of significance of the degree of association between perceived level of neighbourhood disorderliness and the feeling of safety from crime victimization was calculated at 110.919 with a degree of freedom of 6 and a p-value of 0.000 , which is very significant. This presupposes that residents' feeling of safety also derives from their assessment of the level of disorderliness of their neighbourhoods. This result agrees with a plethora of such other researches as Tyler \&Boeckmann (1997); Reisig\& Parks (2000); Sprott\&Doob (2008); Jackson \& Sunshine, (2007) and Jackson \& Bradford, 2008). These studies found that the presence of such incivilities as youths hanging around, public drunkenness and the like, produce information about risk and generate a sense of unease, insecurity and distrust in the environment (Bannister,1993). For Farrall et.al (2009), fear of crime by most people are mere expressions of some broader concernsabout neighbourhood breakdown, loss of moral authority, and the crumbling of civility and social capital. Other urban environmental cues associated with fear of crime or of safety from crime in literature are graffiti and litter (Maxfield, 1987); vandalism (Burgess, 1994); hiding places for criminals, (Hassinger, 1985); disorderly or disreputable behaviour (Biderman et al, 1967).

Table VIII: Relationship between neighbourhood disorderliness/incivility and Residents' feeling of safety

\begin{tabular}{|c|c|c|c|c|c|c|c|c|c|}
\hline \multicolumn{10}{|c|}{$\begin{array}{l}\text { How orderly is your neighbourhood?* How safe do you feel walking alone at night in your } \\
\text { neighbourhood? Cross tabulation }\end{array}$} \\
\hline & & \multicolumn{4}{|c|}{$\begin{array}{l}\text { How safe do you feel walking alone at night in your } \\
\text { neighbourhood? }\end{array}$} & \multirow[t]{2}{*}{ Total } & \multirow[t]{2}{*}{$\overline{D f}$} & \multirow[t]{2}{*}{$x^{2}$} & \multirow[t]{2}{*}{ P.Value } \\
\hline & & Very safe & Just safe & Unsafe & $\begin{array}{l}\text { Very } \\
\text { unsafe }\end{array}$ & & & & \\
\hline \multirow{3}{*}{$\begin{array}{l}\text { How } \\
\text { disorderly } \\
\text { is your } \\
\text { neighbour } \\
\text { hood? }\end{array}$} & $\begin{array}{c}\text { Very } \\
\text { disorderly }\end{array}$ & $1(5.0)$ & $3(15.0)$ & $16(80.0)$ & $0(0.0)$ & $20(100.0)$ & \multirow{4}{*}{6} & \multirow{4}{*}{110.919} & \multirow{4}{*}{.000} \\
\hline & $\begin{array}{c}\text { Fairly } \\
\text { disorderly }\end{array}$ & $140(14.7)$ & 657 (68.9) & $139(14.6)$ & $17(1.8)$ & $953(100.0)$ & & & \\
\hline & $\begin{array}{c}\text { Not } \\
\text { disorderly }\end{array}$ & $22(53.7)$ & $17(41.5)$ & $1(2.4)$ & $1(2.4)$ & $41(100.0)$ & & & \\
\hline Total & & 163 (16.1) & 677 (66.8) & $156(15.4)$ & $18(1.8)$ & $1,014(100.0)$ & & & \\
\hline
\end{tabular}




\section{Binary Logistic Regression for selected socio-demographic variables and feeling of safety among residents in metropolitan Lagos}

Binary logistic regression analysis was performed to establish the nature of the relationship between the socio-demographic variables of sex, age, employment status, religious affiliation, educational status, ethnic group, and income on feeling of safety. The logistic regression model was not significant, $\chi^{2}(4)=21.800 p>.005$. The model explained $4.2 \%$ (Nagelkerke $R^{2}$ ) of the variance in feeling of safety and correctly classified $81.4 \%$ of cases.

Table IX: Binary logistic regression for demographic variable and feeling of safety among residents

\begin{tabular}{|c|c|c|c|c|c|}
\hline & $\mathrm{B}$ & S.E. & $\operatorname{Exp}(B)$ & 95\% C.I & $\operatorname{EXP}(B)$ \\
\hline & & & & Lower & Upper \\
\hline Sex (Male) (RC) & & & 1 & & \\
\hline Female & -.175 & .184 & .839 & .585 & 1.204 \\
\hline $\begin{array}{l}\text { Employment Status (Employed) } \\
\text { (RC) }\end{array}$ & & & 1 & & \\
\hline Unemployed & .568 & .411 & 1.764 & .788 & 3.949 \\
\hline Student/Apprentice & .119 & .330 & 1.126 & .590 & 2.150 \\
\hline Religion (Christianity) (RC) & & & 1 & & \\
\hline Islam & .153 & .219 & 1.165 & .758 & 1.789 \\
\hline Traditional Religion & 1.241 & .781 & 3.458 & .749 & 15.967 \\
\hline Others & -1.177 & 1.455 & .308 & .018 & 5.339 \\
\hline Education (None) (RC) & & & 1 & & \\
\hline Primary & .754 & .481 & 2.126 & .828 & 5.455 \\
\hline Secondary & .956 & .447 & 2.602 & 1.083 & 6.251 \\
\hline Tertiary & .735 & .460 & 2.085 & .846 & 5.140 \\
\hline Ethnic Group (Yoruba) (RC) & & & 1 & & \\
\hline Igbo & -.145 & .232 & .865 & .549 & 1.363 \\
\hline Hausa & .386 & .673 & 1.471 & .393 & 5.508 \\
\hline Others & .810 & .454 & 2.248 & .924 & 5.474 \\
\hline Income (\#20000-\#39999) (RC) & & & 1 & & \\
\hline$\# 40,000-\# 59,999$ & .110 & .250 & 1.116 & .684 & 1.821 \\
\hline \#60,000-\#79999 & .235 & .278 & 1.265 & .733 & 2.183 \\
\hline$\# 80,000-\# 99,999$ & .886 & .413 & 2.426 & 1.079 & 5.451 \\
\hline Age (Less than 20 years) (RC) & & & 1 & & \\
\hline 20-39 years & -.315 & .812 & .730 & .149 & 3.582 \\
\hline 40-59 years & -.258 & .834 & .773 & .151 & 3.965 \\
\hline $60-89$ years & -.382 & .892 & .682 & .119 & 3.918 \\
\hline Constant & .731 & .946 & 2.077 & & \\
\hline Model $\chi 2(p)$ & $21.800(.241)$ & & & & \\
\hline Hosmer and Lemeshow's Test (p) & $4.118(.846)$ & & & & \\
\hline
\end{tabular}

The results reveal that female respondents were less likely to feel safe compared to male respondents. Specifically, the odds of female feeling safe compared to male respondents is 0.839. This result agrees with Ramos and Andrade-Palos (1993) whose study of Mexico City found gender to be the clearest predictor for fear of victimization. Earlier, Ramsay (1989) had also found that while 71percent of women were fearful of being mugged in Coventry, only $47 \%$ of men shared this anxiety. With respect to employment status, the result revealed that unemployed respondents were more likely to feel safe compared to employed respondents. However, the difference is not statistically significant. The result of the analysis also reveals that respondents who were students and artisans were almost as much likely to feel safe compared to employed respondents even though the relationship is not statistically significant. This result contradicts earlier findings in literature. For instance, Hancock, cited in Munice and Wilson (2004) found that those who are less affluent are more likely to be concerned about 
crime. The probable explanation for this new finding may be because the unemployed have no material possessions to make them objects of crime victimization.

Regarding religion, the result revealed that Muslim respondents were more likely to feel safe compared to the Christian respondents, even though the difference is not statistically significant. The result also revealed that respondents who were traditional adherents were more than three times more likely to feel safe compared to Christian respondents. Also, the relationship is statistically significant. A probable explanation is that adherents of the traditional religion do not seem to see themselves in competition with the other two dominant religions and therefore do not see themselves as objects of religious attacks. That Christians are more fearful than the Muslims may also not be unconnected with the Nigeria's long history of religious violence especially in the north of the country, with Muslims often seen as the aggressors.

Regarding educational status, it was found that respondents with primary education are more likely to feel safe compared to those with no formal education. However, the difference is not statistically significant. With respect to respondents with secondary education, the table shows that they are more than two times more likely to feel safe compared to respondents with no formal education. The relationship was found to be statistically significant.This study agrees with the outcome of a recent Gallup-Healthways Well-Being Index survey (cited in Florida, 2013),by the Gallup Organization in the United States of America, which found that a correlation exists between perceived safety and educational levels (measured as the share of adults that are college graduates).

Result of the analysis further reveals that respondents who earn between \#40,000 and $\# 79,999$ are almost as much likely to feel safe compared to those who earn less than \#40,000. However, the odds ratio of respondents who earn above \#80,000 feeling safe compared to those who earn less than \#20,000 is 2.426. That is, respondents who earn above \#80,000 are almost more than two times more likely to feel safe compared to respondents who earned less than \#40,000. This difference is also found to be statistically significant. This study also agrees with the outcome of the Gallup-Healthways Well-Being Index survey which found that the share of city residents who feel safe is positively correlated with income levelsi(Florida, 2013).

With respect to age, the result of the binary regression shows that there is no statistical significance between age and feeling of safety. However, compared to respondents who are below 20 years, every other age group is less likely to feel safe. That is, respondents who are less than 20 years are likely to feel safe compared to all respondents above 20 years. The odds ratio respondents aged 20-39 years, 40-59 years and 60-89 years, feeling safe compared to respondents below 20 years is $.730, .773$ and .668 respectively.

\section{CONCLUSION}

This study investigated factors that underpin the feeling of safety among residents in metropolitan Lagos. The study is among the first of its kind to rigorously examine the predictors of safety among residents in metropolitan Lagos. Earlier works were mostly limited to assessing the fear of crime among residents without rigorous statistical analysis of the social forces that underpin the phenomenon. This work thus complements the previous literature on this subject by showing the nature and degree of influence of identified independent variables on feeling of safety among residents.

Key findings of the study are as follows

- There is a statistically significant relationship between perceived level of crime and experience of feeling of safety among residents in metropolitan Lagos. This is indicated 
by a calculated value (x2) of 99.417, a degree of freedom of 8 and a p-value of 0.000 and interpreted to mean that people are very much likely to feel unsafe or afraid of falling victim to crime if they perceive or consider the rate of crime in a particular environment to be high.

- There is a statistically significant relationship between frequency of crime in neighbourhood and feeling of safety among residents as indicated by a calculated value (x2) of 195.492, a degree of freedom of 4 and a p-value of 0.000 , presupposing that people are very much likely to feel unsafe if they perceive or consider that crime is a regular occurrence in their neighbourhoods.

- The relationship between the regularity of neighbourhood police patrol and feeling of safety among residents is mixed. This is indicated by a calculated value (x2) of 59.897, a degree of freedom of 8 and a p-value of 0.000 .

- The relationship between satisfaction with the performance of the Police and feeling of safety. This is indicated by the chi-square value (x2) of 46.951, a degree of freedom of 2 and a p-value of 0.000 , showing that residents' feeling of safety also derives from their assessment of the effectiveness of the Police in the discharge of their duties.

- There is no statistically significant relationship between level of confidence in the police and residents 'feeling of safety. The chi-square value (x2) for the test of significance of the degree of association between level of confidence in the Police and feeling of safety was calculated at 70.372 with a degree of freedom of 6 and a p-value of 0.000 , indicating that residents' feeling of safety is largely influenced by their level of confidence in the Police.

- There is no statistically significant relationship between crime victimization and feeling of safety. This is indicated by a calculated value (x2) of 69.399, a degree of freedom of 4 and a p-value of 0.000 , interpreted to mean that people who or whose family members had been victims of crime before are very much likely to feel unsafe in a particular environment.

- The influence of levels of disorderliness on feelings of safety was significant statistically. This is indicated by the chi-square value (x2) of 110.919, q degree of freedom of 6 and a p-value of 0.000 , which presupposes that residents' feeling of safety also derives from their assessment of the level of disorderliness of their neighbourhoods.

- The binary logistic regression results reveal that female respondents are less likely to feel safe compared to male respondents with an odd ratio of 0.839 .

- Respondents with secondary education are more than two times more likely to feel safe compared to respondents with no formal education.

- Feeling of safety is positively correlated with income levels. the odds ratio of respondents who earn above \#80,000 feeling safe compared to those who earn less than \#20,000 is 2.426 .

- There is no statistical significance between age and feeling of safety, even though respondents who are less than 20 years are likely to feel safe compared to all respondents above 20 years.

- There is also no significant statistical relationship between employment and feeling of safety although unemployed respondents are more likely to feel safe compared to employed respondents

\section{RECOMMENDATIONS}

As seen here, residents of metropolitan Lagos have palpable fear about their safety from crime victimization. Although perception of safety may not always reflect the actual reality, it does have implications for the flourishing of democracy, economic development, social capital, associational life and the quality of life of citizens. Consequently, the government and all her 
relevant agencies must strive harder to improve citizens' feeling of safety. Accordingly, the following actions are recommended:

- The government needs to take steps to identify neighbourhoods where fear is the highest, and other trends and patterns, including anomalies, such as neighborhoods where crime is low but fear is high' (Cordner 2010).

- The government and other relevant bodies need to conduct environmental audits of public spaces that are commonly identified as unsafe, with a view to developing programmes to improve neighbourhood appearance (Shepherdson, 2014)

- There is also the need for carefully designed neighbourhood cohesion strategies to enhance community connectedness (Ceccato 2012)

- The police and other security groups would need to increase what Cordner (2010) calls 'personalised' beat patrols

- The justice system must be reformed to promote responsibility for behaviour in offenders and enhance victim satisfaction with justice (Borooah and Carcach 1997).

- Finally, since fear is based on perception, it is essential that the public are made aware of any improvements to crime rates or to risk factors associated with fear of crime. Police in particular need to become 'more sophisticated purveyors of reassurance as an antidote to the inevitable messages of mayhem and fear that predominate in politics and the media' (Cordner 2010:x).

\section{Reference List}

Alemika, E.E.O, Igbo, E. \&Nnorom, C. (2006) Criminal victimization, safety and policing in Nigeria: Lagos, CLEEN Foundation, Monograph Study n³, 63p.

Baba, Y. and Mark A. D. (1989) Neighbourhood environmental satisfaction, victimization and social participation as determinants of perceived neighbourhood safety.Environment and Behaviour, 21, 763-780.

Bannister, J. (1993) Locating fear: Environmental and ontological security, In: H.Jones (Ed.), Crime and the Urban Environment. pp. 69-84. Aldershot: Avebury

Bennett, T. (1991) The Effectiveness of a Police initiated fear reducing strategy. British Journal of Criminology, 31, $1-14$.

Biderman, A. D., Johnson, L. A., McIntyre, J., and Weir, A. W. (1967) Report on a pilot study in the District of Columbia on victimization and attitudes toward law enforcement. President's Commission on Law Enforcement and Administration of Justice, Field Surveys I. Washington, DC: US Government Printing Office.

Borooah, V.K, and Carcach, C.A (1997) Crime and fear: Evidence from Australia. The British Journal of Criminology, Volume 37, Issue 4, 1 October 1997, Pages 635-657

Burgess, J. (1994a). The Politics of trust: Reducing fear in urban parks, Working Paper No. 8, Comedia/Demos Study, The Future of Parks and Open Spaces'

In Ceccato, V. (Ed.), (2012) The urban fabric of crime and fear. Dordrecht, the Netherlands: Springer.

Cordner G (2010) Reducing fear of crime: Strategies for Police. Office of Community Oriented Policing Services, U.S. Department of Justice.

Cleen Foundation, (2013) Public presentation of findings of the National Crime victimization survey.Retrieved on January $18^{\text {th }}$ from gallery.mailchimp.com/.../files/Text_Report_of_2013_NCVS_Finding s.pdf (Bennett, 1990).

Chinchilla M., Laura. (2002) Estabilidad social y seguridadciudadana en Centroamérica. In:

SeguridadCiudadana: ¿Espejismo o realidad? pp. 167-187.

Conklin, J.E. (1975) The Impact of Crime. New York: Macmillan.

Cruz, José Miguel. (2008). Violence and insecurity as challenges for democratic political culture in Latin America, Vanderbilt University. Availableonline:http://www.vanderbilt.edu/lapop/ publications.php.

Doyle, M. ,Frogner, L. , Andershed, H. and Andershed, A. (2016) Feelings of safety in the presence of the police, security guards and police volunteers. European Journal on Criminal Policy and Research, 22 (1), 19-40.

Farrall, S., Jackson, J. and Gray, E.( 2009) Social order and the fear of crime in contemporary times. Oxford: Oxford University Press, Clarendon Studies in Criminology. 
Ferraro, K. F. (1995) Fear of crime: Interpreting victimization risk. Albany, NY: State University of New York Press.

Garofalo, J. (1981) The Fear of crime: Causes and consequences, Journal of Criminal Law and Criminology 839 Volume 72 Issue 2 Summer

Grabosky P. (1995) Fear of crime and fear reduction strategies.Australian Institute of Criminology Trends and Issues in Criminal Justice No 44.

Hale, C. (1996), "Fear of Crime: A Review of the Literature", International Review of Victimology, 4: 79-

150.Jackson, J. (2004), 'Experience and Expression: Social and Cultural Significance in the Fear of Crime', British Journal of Criminology, 44/6: 946-966.Ferraro (1995:15

Hassinger.J. (1985) Fear of crime in public environments. Journal of Architectural and Planning Research.2. 289300.

Jackson, J. (2004) Experience and expression: Social and cultural significance in the fear of crime.' British Journal of Criminology, 44, 6, 946-966.

Jackson, J. and Sunshine, J. (2007) Public Confidence in Policing: A neo-Durkheimian Perspective, British Journal of Criminology, 47/2: 214-233. (Tyler and Boeckmann 1997

Jackson, J. and Bradford, B. (2008), Crime, Policing and the Social Order: On the Expressive Nature of Public Confidence in Policing, London School of Economics: Working Paper.

Jackson J., Bradford B,. Hohl K., Farrall S. (2009) Does the fear of crime erode public confidence in policing? Policing: a journal of policy and practice, 3 (1). pp. 100-111. ISSN 1752-

Jackson, J.and Stafford, M. (2009) Public health and fear of crime: A prospective cohort study. The British Journal of Criminology, Volume 49, Issue 6, 1 November 2009, Pages 832-847,

Malone, Mary Fran. (2010) The verdict is in: The impact of crime on public trust in Central

American Justice Systems. Journal of Politics in Latin America, 2 (3): 99-128.

Maxfield, M.G. (1984) Fear of Crime in England and Wales. London: HMSO

Muncie, J. \& Wilson, D. (2004) Student Handbook of Criminal Justice and Criminology. London: Cavendish Publishing Limited.

Odinkalu, C. A. (2005). When did the police become (y)our friend?: Changing roles of civil society in promoting safety and security in Nigeria Crime and policing in Nigeria: challenges and options in Alemika E.E.O and Chukwuma I.C. Eds. Lagos: CLEEN Foundation. Chapter 1: 35- 48

Preisler, J. (2013) Being safe vs. feeling safe. Fostering Perspectives.Vol. 17, No. 2 • May 2013

Reisig, M. D. and Parks, R. (2000) Experience, quality of life, and neighborhood context: A hierarchical analysis of satisfaction with the Police, Justice Quarterly, 17: 607-629.

Silverman, E. B., and Della-Guistina, J. A. (2001) Urban policing and fear of crime. Urban Studies, 38(5), 941-957.

Skogan, W. (1986) Fear of crime and neighborhood change. Crime and Justice, 8, 203-229.

Sprott, J. B. and Doob, A. N. (2008) The Effect of urban neighborhood disorder on evaluations of the Police and Courts, Crime \& Delinquency. Online First, published on February 26, 2008 as doi:10.1177/0011128707306689.

Shepherdson, P. (2014) Perceptions of safety and fear of crime research report. Auburn City Council in partnership with Bankstown, Canterbury and Hurstville Councils.

The Overseas Security Advisory Council (OSAC) United States Bureau of Diplomatic Security (2015). 2015 Nigeria Crime and Safety Report. (https://www.osac.gov/pages/ContentReportDetails.aspx?cid=17577)

Tyler TR and Boeckmann R.J (1997) Three strikes and you are out, but why? The psychology of public support for punishing rule breakers. Law and Society Review 31: 237-265.

Veer, E. van de; Lange, M.A. de; Haar, E. van der; Karremans, J.C. (2012) Feelings of Safety: Ironic Consequences of Police Patrolling. Journal of Applied Social Psychology 42 (2012)12. - ISSN 0021-9029 - p. 3114 - 3125. 